\title{
The use of the linear reservoir concept to quantify the impact of changes in land use on the hydrology of catchments in the Andes
}

\author{
W. Buytaert ${ }^{1,2}$, B. De Bièvre' ${ }^{1,2}$, G. Wyseure ${ }^{3}$ and J. Deckers ${ }^{1}$ \\ ${ }^{1}$ Laboratory for Soil and Water Management, Katholieke Universiteit Leuven, Belgium \\ ${ }^{2}$ Programa para el Manejo del Agua y del Suelo PROMAS. Universidad de Cuenca, Ecuador \\ ${ }^{3}$ Faculty of Agricultural and Applied Biological Sciences, Katholieke Universiteit Leuven, Belgium \\ Email for corresponding author: Wouter.Buytaert@agr.kuleuven.ac.be
}

\begin{abstract}
The high Andes region of South Ecuador (The Páramo) is characterised by a cold and wet climate. Most soils of the Páramo region are Andosols and Histosols, with a very high water retention capacity that is affected irreversibly by drying. This key property of Páramo soils buffers catchment outflow, resulting in an almost uniform outflow pattern which, notwithstanding the variability in rainfall, can be very variable in space and time. These soils serve as the most important reservoir of drinking and irrigation water for the densely populated interAndean depression region. The Páramo has long served only as an extensive grazing area but recent population pressure and land scarcity have increased cultivation. Two small Páramo catchments (about $2 \mathrm{~km}^{2}$ ) were monitored intensively for precipitation and discharge for over a year to assess the effect of such land-use changes on the hydrological properties. One catchment is in an undisturbed area and grazed intensively while in the other, local farmers started intensive drainage for cultivation of potatoes about five years ago. The linear reservoir concept has been used to assess the overall retention capacity of the catchments in terms of both peak response and base flow. In this model, every catchment is considered as a series of independent parallel reservoirs, each characterised by mean residence times (T). In every catchment, three major mean residence times can be distinguished. In the undisturbed catchment, an immediate response, characterised by a $\mathrm{T}$ of 5.4 hours, is followed by a slower response with a $\mathrm{T}$ of $44.3 \mathrm{~h}$. The base flow has a mean $\mathrm{T}$ value of $360 \mathrm{~h}$. The response of the cultivated catchment is similar with T values of $3.6 \mathrm{~h}, 27.2 \mathrm{~h}$ and $175 \mathrm{~h}$, respectively. As a result, in the disturbed catchment, water release is about $40 \%$ faster than in the undisturbed catchment, so that the base flow falls rapidly to lower levels. The linear reservoir model is a simple way of quantifying the impact of land use changes on the water regulation capacity of Páramo catchments.
\end{abstract}

Keywords: linear reservoir, Páramo, mountain hydrology, land use changes, Ecuador

\section{Introduction}

Water supply is of great economic and social importance in many parts of the world. The southern Ecuadorian Andes region, called the Austro Ecuatoriano, is not particularly dry but, as rainfall can be very variable in space and time, investments in water supply systems to bridge large periods of rainfall scarcity are very important. Water demand is increasing, and more attention is now being paid to the reliability of water supply, particularly in industrial and highly populated areas.

Because groundwater is almost non-existent, those water uses are completely dependent on surface water or streams rising in the Páramo in the Andes above $3500 \mathrm{~m}$ a.s.l. (Medina and Vásconez, 2001). These water sources are not only fairly well regulated but also, because of the lack of pollution in the area except for airborne deposits and some livestock effluent, offer good quality water. Rainfall averages between 1200 and $2000 \mathrm{~mm}$ a year. Vegetation comprises small grass species and widely scattered patches of quinoa trees (Polylepis) (Hedberg, 1992; Luteyn et al., 1992). The region is also characterised by non-allophanic Andosols in the north, evolving towards Histosols in the south (Driessen et al., 2001, Buytaert et al., 2003), both having a very high water retention capacity of up to over $80 \%$ vol. at field capacity (Poulenard et al., 2001; Buytaert et al., 2002). They act as a buffering reservoir and turn the variable rainfall into a continuous water discharge of rivers that originate in the Páramo; of these, the Rio Paute is the most important in 
the Austro Ecuatoriano (Fig. 1). Figure 2 shows the hydrograph for two similar rainfall events. The first is in the Huagrauma Páramo catchment with Histic Andosols, while the second originates from a 'normal' catchment in a lower region, characterised by clayey Cambisols. The water release of the Páramo catchment is slow while the clay soil catchment registers zero discharge after rainfall stops. As the buffering capacity of the vegetation cover is very small, the Andosols are responsible for this water buffering capacity.

Human-induced land-use change in the Páramo is beginning to have a significant effect on the water supply. Removal of the natural vegetation leads to higher surface runoff, less infiltration and exposes the soil to severe drying, as radiation can be very high at this altitude (>3500 $\mathrm{m}$ a.s.1.) and latitude ( 2 to $3^{\circ} \mathrm{S}$ ) (Hofstede, 1995), something to which these soils are very vulnerable (Poulenard et al., 2001; Buytaert et al., 2002) as they suffer from irreversible loss of water retention capacity when dried out (Nanzyo et al., 1993; Basile and De Mascellis, 1999). While such water retention losses can be studied in the laboratory using undisturbed soil samples, it is difficult to estimate the real impact on the hydrology; small samples and laboratory experiments differ from real world situations (Beven, 2001). Furthermore, field situations may involve other mechanisms such as faster artificial drainage and larger surface runoff. Hence, modelling using a straightforward lumped concept has been adopted here.

\section{Modelling approach}

Most distributed models are based on an extensive set of laboratory derived relations and use a reductionist approach to model the basic physical processes of large, complicated catchments. This requires not only a large dataset of both field data and laboratory-derived parameters but also doubts can arise about the accuracy and applicability of these data at larger scales. Furthermore, the reductionist strategy is vulnerable, either to oversimplification or overparametrisation. In using hydrological modelling to predict the hydrological consequences of land-use changes, over-simplification can lead to a lack of predictive capacity and a poorly calibrated model, while overparametrisation can lead to a wide range of feasible parameter sets and, hence, to large errors in predictions (Beven et al., 1995; Woolridge et al., 2001).

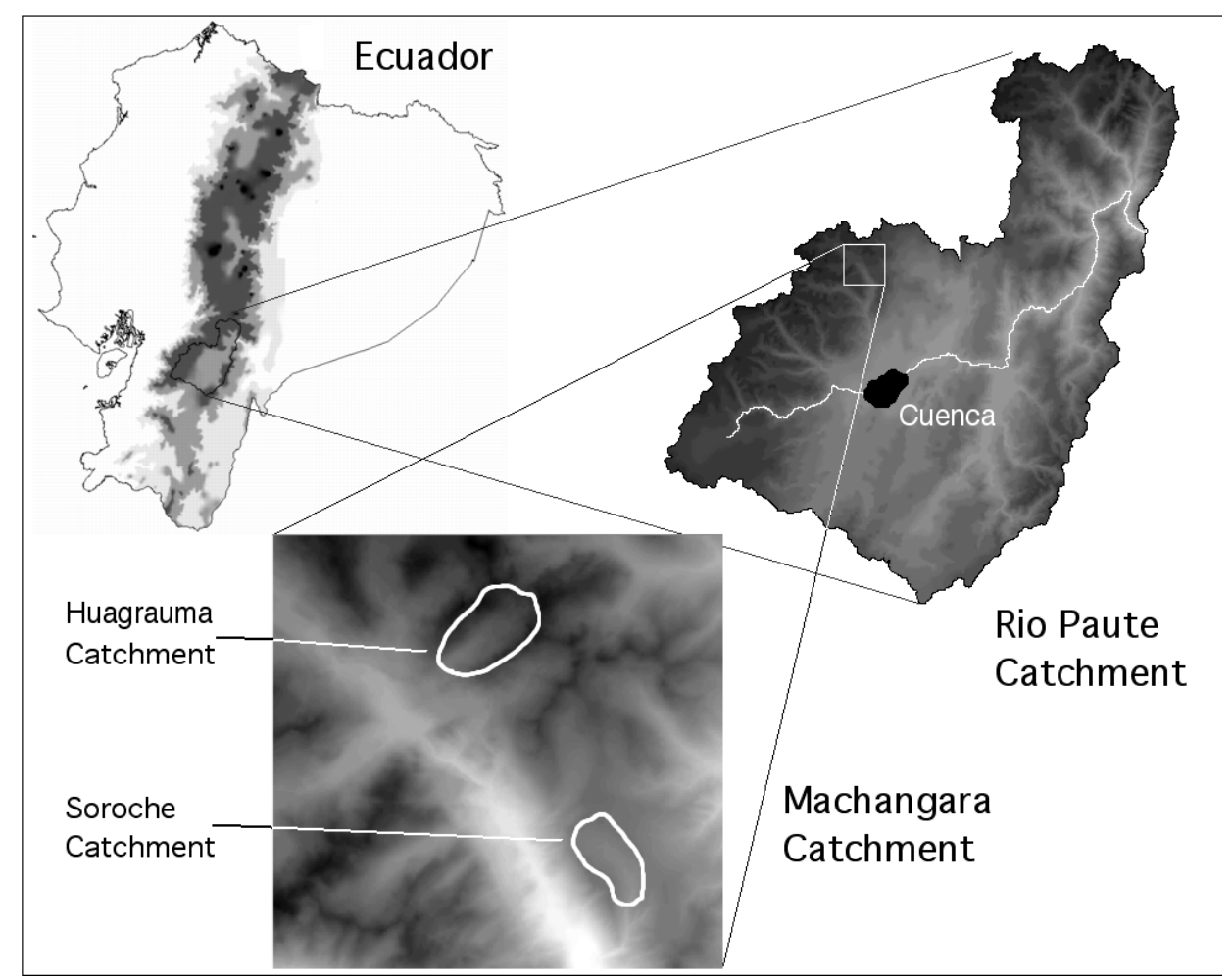

Fig. 1. Location of the experimental Páramo catchments Chanlud (natural) and Soroche (disturbed) within the Rio Paute catchment, Austro Ecuatoriano, southern Ecuador. 
Chanlud catchment

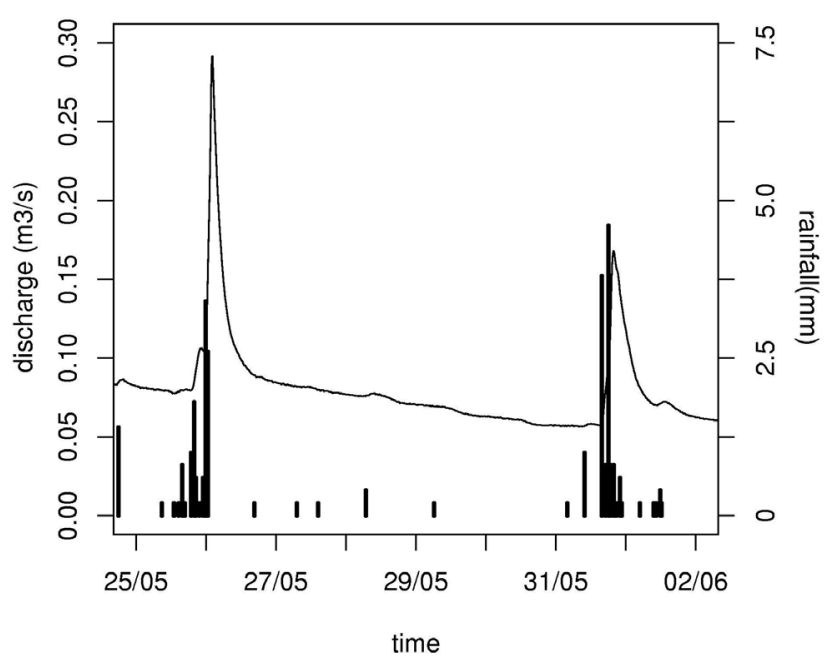

Laberinto catchment

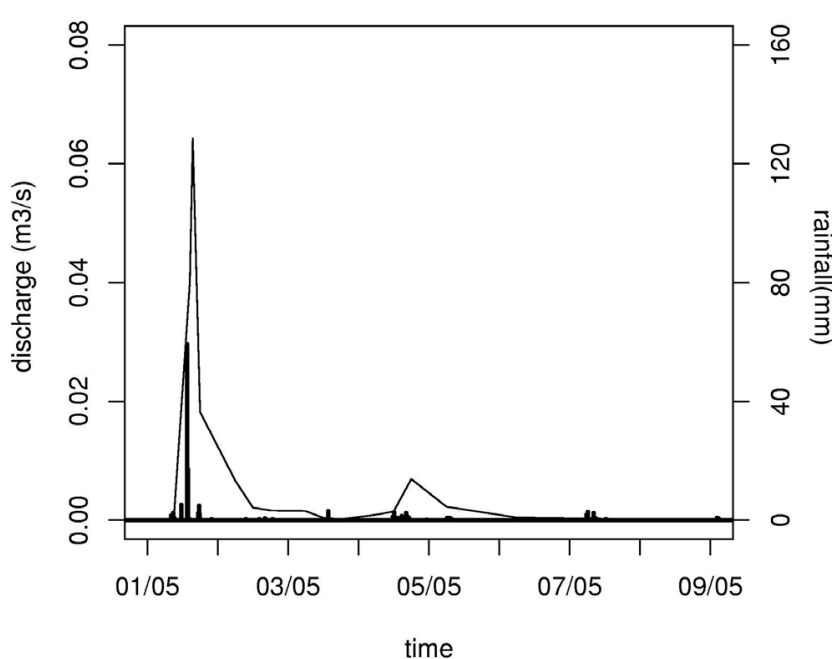

Fig. 2. Comparison of the hydrological response on a similar rainfall event of a Páramo catchment (Chanlud) versus a "normal" clayey soil catchment (Laberinto) in the same region.

In this study of land-use changes in the Austro Ecuatoriano, two small and very similar catchments in the same region were monitored; in these, all the hydrological characteristics were as identical as physically possible, except for the factor to be studied. The straightforward linear reservoir model was applied to both, summarising in a few parameters the combined effect of the different land uses on the hydrology of both catchments.

\section{Materials and Methods}

Within the Machangara catchment near the city of Cuenca (Fig.1), two micro catchments were chosen in a similar geomorphological setting and three km apart.(Table 1). Each was equipped with three tipping bucket rain gauges with a resolution of $0.2 \mathrm{~mm}$. At the outlet of each catchment, the outflow was measured every 15 minutes at a v-notch weir with a water level logger. The outflow accuracy is estimated at $5 \mathrm{~L} \mathrm{~s}^{-1}$, resulting in a database of detailed and precise discharges. The soils of the catchments are Histic Andosols and Histosols (Driessen et al., 2001), with a saturated water retention capacity of about $0.9 \mathrm{~cm}^{3} \mathrm{~cm}^{-3}$ dropping to $0.7 \mathrm{~cm}^{3} \mathrm{~cm}^{-3}$ at wilting point $(\mathrm{pF}=4.2)$. The $\mathrm{pF}$-curves determined by the multistep outflow method (Inoue et al., 1998) on undisturbed soil samples in kopecky rings $\left(100 \mathrm{~cm}^{3}\right)$ are shown in Fig. 3. Natural vegetation, a tough grass species, has been replaced by more nutritive species in the cultivated Soroche catchment and in part of this catchment, the vegetation has been removed for cultivation of potatoes.
Table 1. Characteristics of the two catchments that are monitored and modelled to assess the influence of land use changes.

\begin{tabular}{lll}
\hline Catchment name: & Huagrauma & Soroche \\
\hline Area: & $2.3 \mathrm{~km}^{2}$ & $1.9 \mathrm{~km}^{2}$ \\
Land use: & extensive grazing & $\begin{array}{l}\text { intensive grazing, } \\
\text { cultivation and } \\
\text { drainage }\end{array}$ \\
Soil type: & Histic Andosols & Histic Andosols \\
& and Histosols & and Histosols \\
Altitude range: & $3690-4100 \mathrm{~m}$ & $3520-3720 \mathrm{~m}$ \\
\hline
\end{tabular}

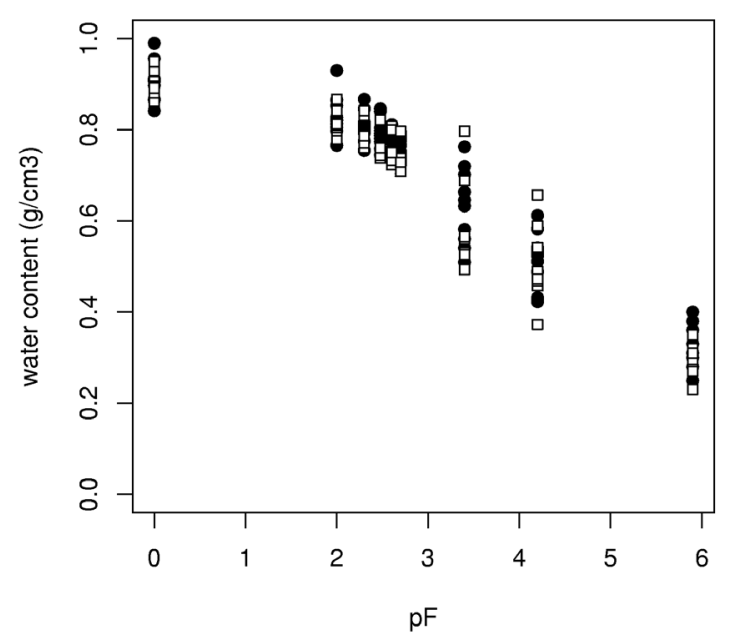

Fig. 3. The pF-curves of the Histic Andosols of the catchments show a very high water retention capacity, resulting in the typical large buffering capacity. $\bullet=$ Soroche. $\boldsymbol{\square}=$ Chanlud. 


\section{The linear reservoir concept}

The linear reservoir concept is based on analysis of the recession limbs of the drainage hydrographs, and has already been used extensively for description of catchment responses (Linsley et al., 1988; Hornberger et al., 1991; Dingman, 1994; Sivapalan et al., 2002). It can be described as:

$$
\mathrm{Q}=\mathrm{k} \mathrm{S}
$$

$$
\mathrm{dS} / \mathrm{dt}=-\mathrm{Q}
$$

where $\mathrm{Q}$ is the outflow, $\mathrm{S}$ is the stored amount of water, $\mathrm{t}$ the time and $\mathrm{k}$ is a rate constant. With $\mathrm{k}=1 / \mathrm{T}$, these equations can be combined in:

$$
\mathrm{Q}=\mathrm{Q}_{0} \exp (\mathrm{t} / \mathrm{T})
$$

with $\mathrm{Q}_{0}$ being the outflow at $\mathrm{t}=0$. This equation is linearised in a semilogarithmic plot:

$$
\ln Q=\ln Q_{0}-t / T
$$

The rate constant $\mathrm{k}$, which is the inverse of the time constant $\mathrm{T}$, is an index of the speed at which a reservoir drains. Mathematically, $\mathrm{T}$ is the time at which the outflow
$\mathrm{Q}$ falls to a value of $\mathrm{Q}_{0} / \mathrm{e}$ or $0.37 \mathrm{Q}_{0}$. Thus, $\mathrm{T}$ indicates the buffering capacity of a reservoir or the 'slowness' of the water release. As such, it is a good estimator for the water buffering capacity of the water storage reservoir, S.

Very few catchments can be described using the linear reservoir model as such because of the diverse types of reservoirs, such as surface water storage, soil water retention, interception by vegetation, lakes and groundwater. All have their own time constants and some do not comply with the assumption of linearity, leading to a non-linear behaviour of the recession limb, when plotted semi-logarithmically. However, in small catchments, some of these reservoirs are more important than the others. In the catchments being examined here, the grass which dominates the vegetation has little impact on the hydrology and can be neglected; also, lakes and groundwater sources are absent and so do not have to be taken into account. Furthermore, rainfall is likely to fall over the whole catchment, leading to a more uniform input and hydrographs that can be interpreted more easily. The catchment can, then, be seen as a parallel chain of reservoirs with different $\mathrm{T}$ values. When these $\mathrm{T}$ values differ sufficiently, interference can be neglected, and the resulting regression/recession limb is a temporary chain of releases from different reservoirs (Fig. 4). These linear sectors can be identified in the semilogarithmic plot of the

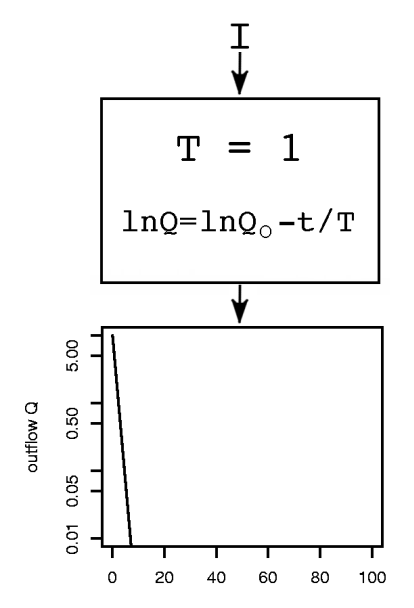

time
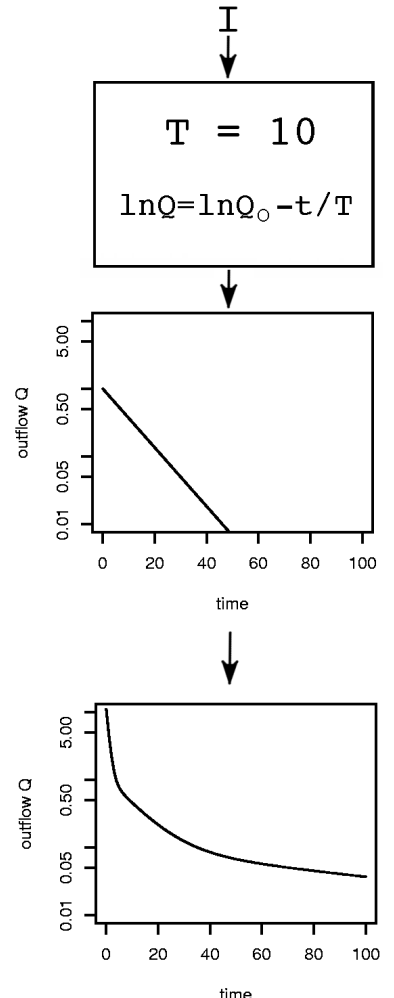

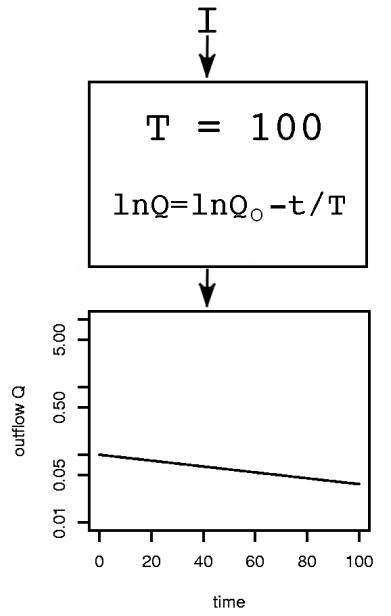

time

Fig. 4. Conceptual representation of the linear reservoir model. Each reservoir is characterised by a time constant $T$ and placed in parallel with other reservoirs to create the final discharge. 


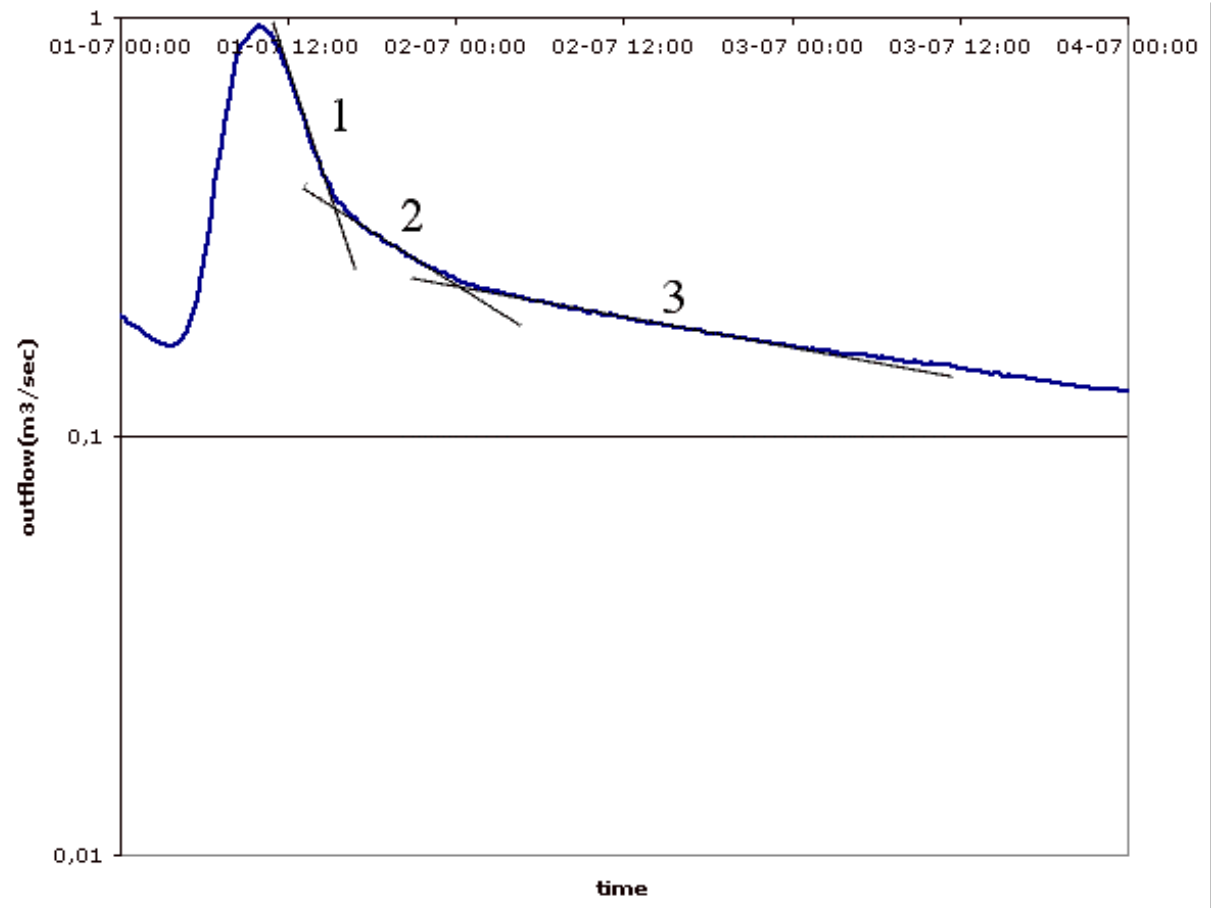

Fig. 5. In the semilogarithmic plot of a hydrograph limb of a small catchment, linear sections can be distinguished, indicating the relative importance of particular linear reservoirs in this recession curve.

recession limbs, each representing a theoretical reservoir with a particular time constant $\mathrm{T}$ that can be determined directly from the slope of the linear part:

$$
1 / \mathrm{T}=-\delta \ln \mathrm{Q} / \delta \mathrm{t}
$$

Furthermore, as long as no type of reservoir becomes relatively more important (such as groundwater sources in a very dry period when surface runoff is zero and the soil water is depleted), these time constants are more or less equal over different recession limbs. Figure 5 shows a semilogarithmic hydrograph of the Huagrauma catchment in which three linear parts are clearly visible.

\section{Results and discussion}

The regression limbs of peaks of fairly similar rainfall events in both catchments were analysed graphically and analytically. Out of an outflow dataset of 14 (Huagrauma) and 12 (Soroche) months, respectively, 24 and 18 peaks were selected, each corresponding to a homogeneous and regular rain event, without secondary peaks.In these peaks, two fast time constants could be detected and, when the rainfall event was followed by a dry period of at least a day, a slower third time constant appeared in the base flow (Fig. 6). The choice of three linear segments is not only based on graphical analysis, but is also supported by field

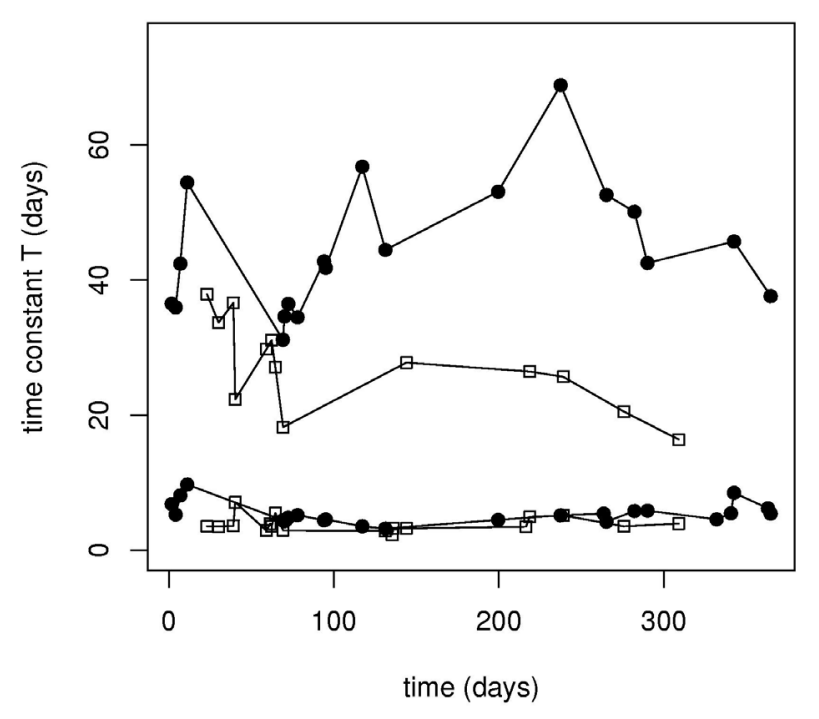

Fig. 6. The time constant $T$ values encountered in the recession limbs of the discharge of the catchments are stable over time. The circles indicate the natural Chanlud catchment, while the squares represent discharge from the disturbed Soroche catchment.

observations. Due to the mountainous terrain and the impenetrable bedrock, deep percolation is small, and the major hydrological processes occur in the soil layer. Besides saturated overland flow, major subsurface flows were observed at the border between the $\mathrm{H}$ and A horizon (+/- 30 
cm depth) and at the border between the A horizon and the bedrock (+/- $80 \mathrm{~cm}$ depth). It is likely that these processes correspond to the conceptual reservoirs.

Âîer an unpaired sampies T-iesi ố equai medns, ine datasets of each time constant $\mathrm{T}$ differ significantly between both catchments. The means, variance, and probability values for equal means $(\mathrm{P})$ of the time constants are in Table 2. The $P$ value of the third time constant is higher because the dataset is smaller.

Theoretically, the time constant is independent of the area of the catchment, which is represented in the model via the storage capacity $\mathrm{S}$. The linear model is linear only as long as $\mathrm{T}$ is independent of $\mathrm{S}$. In a real-world situation, this assumption is incorrect, as different routing mechanisms have to be taken into account. As long as the drainage density of the catchments being compared is more or less equal and the time water spends in the routing system can be neglected, (which is the case in small mountainous catchments with a short and fast routing), then the linear reservoir concept can be used to model and compare catchments. Furthermore, it is unlikely that a difference in catchment area of about $17 \%$ between Huagrauma and Soroche would result in a difference of more than $50 \%$ in $\mathrm{T}$ (Table 2). Also, since the natural Huagrauma catchment has steeper slopes (Table 1) that would lead to faster surface runoff and subsurface drainage and, thus, a faster response, a smaller buffering capacity and a smaller $\mathrm{T}$ value would result. However, this is not observed. Hence, it is very likely that artificial drainage and changes in the hydrophysical soil properties account for a large part of the difference between the catchments and, largely, surpass the differences in slope steepness. It can be concluded that the response of the disturbed catchment is $40 \%$ faster than that of the undisturbed catchment and that the buffering capacity, of which the largest part is due to land use changes, is comparably smaller. The model makes no assumptions regarding the different mechanisms by which changes in land use reduce the hydrological buffering capacity of the catchment. Several field and laboratory procedures are available to quantify particular effects on hydrophysical soil properties. However, the model gives a good general and holistic picture of how the different actors interact at the field scale, something very few laboratory experiments or even distributed hydrological models are able to achieve.

Attention must be drawn to the fact that experimental design is very important when using the linear reservoir concept for modelling, as the assumptions that have to be fulfilled make the model rather selective in its application. On the other hand, whether or not the hydrological response of a catchment is in accordance with the model can easily be checked using the inverse semi-logarithmic plot. When appropriate, the linear reservoir concept is an excellent tool for fast and physically sound hydrological catchment characterisation that can obviate large and expensive data collection, model development and calibration.

\section{Conclusions}

The linear reservoir model has proved to be an adequate estimator of overall land use influence on the hydrological characteristics of small mountainous catchments. Through the time constant $\mathrm{T}$, the model is able to integrate land use influences into one mathematical parameter with direct physical meaning, being the inverse of the buffering capacity of the catchment.

Modelling small and very similar catchments is an easy way to identify, directly, effects of changes in hydrological parameters on hydrological behaviour and so eliminates the need for complex distributed models, large datasets and extensive calibration.

Use of the linear reservoir model on two Páramo catchments in the Austro Ecuatoriano, southern Ecuador, has shown that changes in land use can diminish water retention and buffering capacity of the soils by about $40 \%$. These results stress the importance of an adequate land-use planning system, to safeguard water supply and avoid the risks of increased erosion and flooding.

\section{Acknowledgements}

The authors would like to thank Dr. Felipe Cisneros, director of PROMAS, the programmme for water and land

Table 2. Time constants $\mathrm{T}$ of the linear reservoir model

of the natural catchment Huagrauma and of the disturbed catchment Soroche, and the reduction due to land use.

\begin{tabular}{lcccccc}
\hline & Huagrauma & Variance & Soroche & Variance & Difference & $P$ \\
\hline T1 (h) & 5.4 & 2.38 & 3.6 & 1.32 & $-33 \%$ & $<0.001$ \\
T2 (h) & 44.3 & 92.6 & 27.2 & 44.68 & $-39 \%$ & $<0.001$ \\
T3 (h) & 360 & 2141.58 & 175 & 976.25 & $-51 \%$ & 0.032 \\
\hline
\end{tabular}


management at the University of Cuenca, for the logistical help provided during the fieldwork, as well as the Fund for Scientific Research, Flanders, of which Buytaert is a researcher.

\section{References}

Basile, A. and De Mascellis, R., 1999. Change of hydraulic properties and solute transport parameters in volcanic ash soils after drying. In: Modelling of transport processes in soils at various scales in time and space, J. Feyen and K. Wiyo (Eds.). Proceedings of the International Workshop of EurAgEng's Field of Interest of Soil and Water, November, 24-26, Leuven, Belgium. 267-275.

Beven, K., 2001. Rainfall-Runoff Modelling. Wiley, Chichester, UK.

Beven, K., Lamb R., Quinn P., Romanowicz, R. and Freer J., 1995. Topmodel. In: Computer Models of watershed hydrology, V.P.Singh (Ed.). Water Resources Publications, Colorado, USA. 627-668

Buytaert, W., Deckers, J., Dercon, G., De Bièvre, B., Poesen, J. and Govers, G., 2002. Impact of land use changes on the hydrological properties of volcanic ash soils in South Ecuador. Soil Use Manage., 18, 94-100.

Buytaert, B., Duyck, H., Dercon, G. and Deckers, J., 2003. The genetical relationship between Andosols and Histosols in South Ecuador. Catena. In press.

Dingman, S.L. 1994. Physical hydrology. Macmillan, New York, USA.

Driessen, P., Deckers, J., Spaargaren, O. and Nachtergaele, F., 2001. Lecture notes on the major soils of the world. Number 94 in World Soil Resources Reports. FAO, Rome, Italy..

Hedberg, O., 1992. AfroAlpine vegetation compared to páramo: convergent adaptations and divergent dierentiation. In: Paramo: an Andean ecosystem under human influence, H.Balslev and J.L.Luteyn (Eds.) Academic Press, London, UK. 15-30.

Hofstede, R.G.M., 1995. Effects of burning and grazing on a Colombian páramo ecosystem. $\mathrm{PhD}$ thesis, Universiteit van Amsterdam, The Netherlands.

Hornberger, G.M., Germann, P.F. and Beven, K.J., 1991. Throughflow and solute transport in an isolated sloping soil block in a forested catchment. J. Hydrol., 124, 81-99.

Inoue, M., Simunek, J., Hopmans, J.W. and Clausnitzer, V., 1998. In situ estimation of soil hydraulic functions using a multistep soil-water extraction technique. Water Resour. Res., 34, 10351050 .

Luteyn, J. L., Cleef, A. M. and Rangel, O., 1992. Plant diversity in páramo: towards a checklist of páramoplants and generic flora. In: Páramo: an Andean ecosystem under human influence, $\mathrm{H}$. Balslev and J.L.Luteyn, (Eds) Academic Press, London, UK. 71-84.

Medina, G. and Vásconez, P.M., 2001. Los páramos en el Ecuador. In: Los páramos del Ecuador. P.M.Vásconez, G. Medina and R.Hofstede (Eds.), Proyecto Paramo, Quito, Ecuador.

Nanzyo, M., Shoji, S. and Dahlgren, R., 1993. Volcanic Ash Soils: genesis, properties and utilisation. Developments in Soil Science $\mathrm{N}^{\circ} 21$. Elsevier, Amsterdam, The Netherlands.

Poulenard, J., Podwojewski, P., Janeau, J. L. and Collinet J., 2001. Runoff and soil erosion under rainfall simulation of andisols from the Ecuadorian páramo: effect of tillage and burning. Catena, 45, 185-207.

Sivapalan, M., Jothityangkoon, C. and Menabde, M., 2002. Linearity and nonlinearity of basin response as a function of scale: Discussion of alternative definitions. Water Resour. Res., $38,4.1-4.5$.

Wooldridge, S., Kamla, J. and Kuczera, G., 2001. Parametrisation of a simple semi-distributed model for assessing the impact of land-use on hydrologic response. J. Hydrol., 254, 16-32. 